\title{
Analyzing of Investment Strategies of Local Companies in Azerbaijan: Problems and Solutions
}

\author{
Fariz Ahmadov, Matanat Salmanova \\ Azerbaijan State Economic University, Baku, Azerbaijan
}

\begin{abstract}
For businesses to be viable nowadays they must be able to invest successfully. Globalization insists that businesses track new innovations and remain open to the idea of change. In addition, businesses need to stay informed of new technological trends, retain the shareholders they already have, and be ready to invest in innovative technologies when they are introduced. Through these strategies, businesses can be competitive in the marketplace. Short- and long-term planning is necessary to identify the direction of both investments and new projects and project ideas. Two major obstacles to implementing these pre-planned strategies are insufficient in-house resources and lack of access to loans. Companies need to be realistic about what they are capable of and make sure that all new ventures tie into the existing capabilities instead of risking starting a product or service unrelated to the existing business. Projects that are undertaken must be thoroughly researched as alternative options in case the need arises to change direction. Companies should be prepared with a plan and be prepared to move to a secondary plan if the first plan meets with obstacles. In this way, companies can be well informed, prepared, and still versatile enough to meet the needs of the globalized competitive market. A proposed article describes details of the theoretical part of the business investment strategy. The themes of the research are mainly about identification of economical perspectives of the investment, type of investment, identification of investment strategy overview, and its components as well as forming of investment strategy stages. Afterwards, in proposed investigation taken place analyzing of investment risks that might be faced by companies focusing on business investment and their investment capacity based on exist strategy. Research methodology included survey, interview, and critical literature. At the end of research work, it provided expected results of the development of the investment strategy of local companies situated in Azerbaijan.
\end{abstract}

Keywords: investment, strategy of investment, investment analyzing, local companies

\section{Theoretical Grounds of a Company’s Investment Strategy}

Until 80s of the 20th century, investment could only be come across in American and European literatures. Basic definition of investment activity was capital investment. However, capital investment is a narrow definition, as it only means investments in main foundations. Other economic resources such as information resources, securities, and material reserves were not considered as investments.

Fariz Ahmadov, Ph.D., Associate Professor, Department of Economy and Business Administration, Azerbaijan State Economic University.

Matanat Salmanova, Research Assistant, Azerbaijan State Economic University, Turkish World Business Administration Faculty.

Correspondence concerning this article should be addressed to Fariz Ahmadov, Baku, H. Aliyev, str., 135, Azerbaijan. E-mail: farizazeri@yahoo.com; salmanova_m@hotmail.com. 
Later, investment started to be used as a term in normative documents. After that, investment was understood widely, not only as capital investment in main foundations, but also as in circulation foundations. Investment activity of a company cannot be restricted with satisfaction of current investment demands. In modern world, many companies understand the reasonable management of investment activities based on scientific methodology of bringing the company in accordance with changing investment environment and general goals of the company. Investment strategy is an effective tool of managing a company's investment activity in a perspective. Investment strategy reflects a system of long-run goals of a company's investment activities. It stipulates company's general development objectives, investment ideology, and the most effective ways of fulfilling these objectives. Investment strategy expresses the major direction of a company's investment activity. Investment strategy determines the priorities of a company's investment activity, its directions and stages of the formation of investment resources, and implementation of long-run investment goals.

Process of the development of an investment strategy is an important part of a company's general strategic activities.

Factors determining company's value also prove that investment strategy is a major strategy of a company.

The essence of investment strategy is a set of decisions on how to get useful resources, time, and conditions in order to reach company's goals and how to transfer them to capital investment considering various factors. Of course, general strategy to certain extent plays an important role in choosing the investment strategy, as it determines the development of the company as a target. Company's economic and financial situation related to the future of the company, being a result of the company's economic decisions and determining the company's financial state is no less important (Ahmadov, 2010). Depending on state of finance of companies, they make huge, risky, small, and less investment, as it requires fewer costs. Company's state of finance depends on its experience which shows its skills of making incomes and cash. According to banking degrees, the company's state of finance is related to the company's credit capacity. As for banks, experience of company in returning its outstanding service and investment credits is a basic condition after getting such credits. Investment strategies of companies also regulate their relations with other actors of investment market which create investment processes. These actors are investors, finance and law firms, and companies dealing with environmental protection. Rules and mechanism of regulation of a company's development activities have a direct influence on the investment strategy of the company. Investments of a company may always be subject to serious loss and the amount and nature of risks usually derive from indefinite character of investment processes. For instance, the amount of time necessary for attaining investments and the amount of incomes are made as an outcome of investments. It could be concluded that company's investment strategy is also dependent on company's skills of showing efforts and making risks. Risks may have positive and also negative influences on investment processes. For example, it could either speed the process up, or slow it down. Thus, risk is related to management and should be clearly determined. It is important to define favorable limits in investment processes and the amount of activities directed towards motivation. The investment strategy of companies is also regulated with innovations being an integral part of cultural and technical development. Likelihood of applying changes, such as presenting new, useful products, technologies, and services, is one of the main attributes of companies. Companies need to demonstrate innovations and be ready to offer new products and services to the market. So, designing an optimal investment structure of a company requires considering all determining factors and choices that ensure the company's development. The basic factors of 
company’s investment strategy are specified in Figure 1.

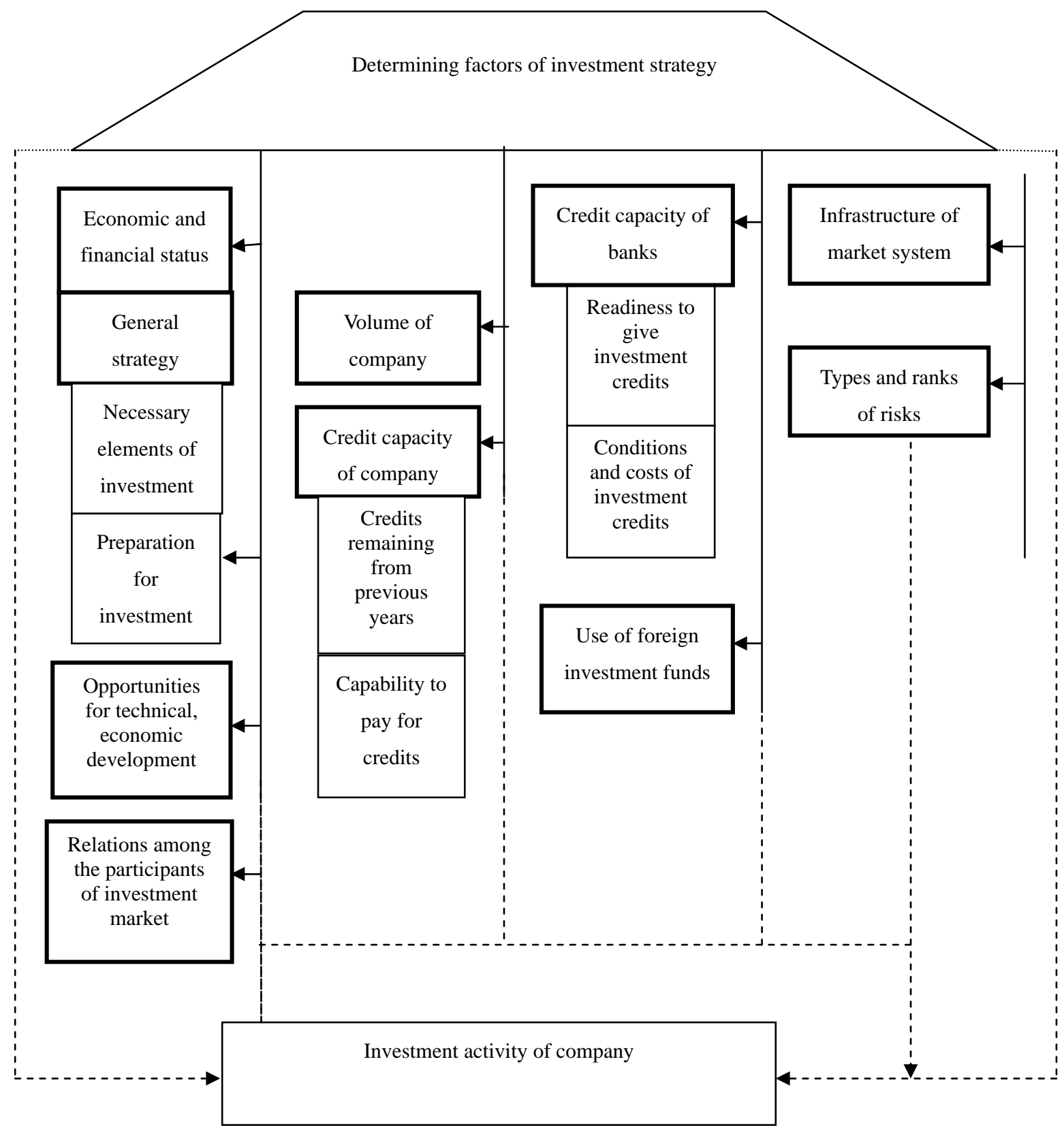

Figure 1. Basic factors of investment strategy in the development of a company (Ostrowska, 2002).

\section{Expected Life Periods of a Company}

Each period of a company's life has specific level and direction of investment activity. The present period of life of a company differentiates strategic goals of its investment strategy. In its childhood period, company forms its main strategic goals that would further provide high temp of its real investment activities. In youth period, the main strategic goals of a company may increase the volume of real investments, diversify directions of investment, and ensure minimum norms of current income. In maturity period, the main strategic goals of company could ensure to reach the critical point of investment amount, maintain the critical point of investment 
amount, create portfolio investments and ensure wide diversification of real investments, and ensure increasing temp of investments and average norm of investment incomes. In senility period, the strategic goals of investment strategy could be renovation of assets that have been subject to amortization, compress of investment portfolio, and invest more resources to maintain necessary level of activities.

\section{Change of External Investment Environment}

The dynamic of macroeconomic indicators related with company's investment activity, temp of scientific and technical progress, changes in the priorities of the investment market, and changes in the government regulation of investment market do not allow companies to effectively manage its investments solely based on its experience and traditional methods of financial management. And if a company does not have an investment strategy adapted to an external investment environment, various sectors of the company's organizational structure will make different investment decisions that will in due course cause a decrease in the efficiency of investment activities.

\section{Changes in the Company's Goals Due to New Business Opportunities}

These changes require diversification of products, application of new technologies, and occupation of new markets. Under these conditions, the company's investment activities and its diversification could be forecasted.

\section{Principles and Stages of the Formation of a Company's Investment Strategy}

Formation of investment strategy is based on the following principles:

- Company shall be a self-organized, open, and social economic system. The essence of this principle of strategic management is that the preparation of the investment strategy of a company is considered to be a system open for active reciprocal relationships with the factors of external investment environment;

- The accordance of company's activities with basic strategy: Company's investment strategy is a part of the company's strategy of economic development that ensures the improvement of the company's activities and therefore shall be in accordance with the general goals and directions of the company;

- Accordance of investment activity with the basic factors of strategic management: In a strategic perspective, the company's investment behavior is related to the company's style of entrepreneurship and growth. Ground of growth style of investment behavior consists of minimization of alternatives of adopted investment decisions and setting strategic goals in accordance with achieved level of activity. It also consists of the search of effective investment decisions on all stages, forms, and directions of investment activity;

- Ensuring proper perspective, current and operative management of investment activity: According to the concept of strategic management, company's ready investment strategy becomes more concrete with the formation of investment program (portfolio) in the process of current management. Unlike the investment strategy, formation of an investment program is medium-run management process and is realized within the company's current investment opportunities and strategic decisions;

- Adaptation of investment strategy to the change of factors of external investment environment: Essentially it means that all expected changes in investment activity, such as changes in its directions, forms, methods of planning, control may be forecasted about, either their demand operative reaction against such changes. If forecasted parameters are relatively stable, the company is capable to make its strategy in detail and to design tougher organizational structure for the management of its investment activity; 
- Ensuring alternatives in choice of strategic investment: Searching for alternative options, the choice of the best of them and developing a strategy on the choice and its realization is a basis of strategic investment decisions. The existence of alternatives is a main feature of strategic management and is related to basic elements of choice of strategic investment;

- Using the results of technological achievements on a permanent basis: While developing an investment strategy, one should consider that investment activity is a main mechanism of the application of technological innovations. Therefore, the company's achievement of its general goals is dependent on how the strategy reflects technological innovations and how well it is adapted for their application in company's investment activities;

- Considering the level of investment risks in making strategic decisions: All decisions made in the field of investment strategy to a certain extent change the level of risk. The formation of company's investment strategy passes through the following stages in Figure 2.

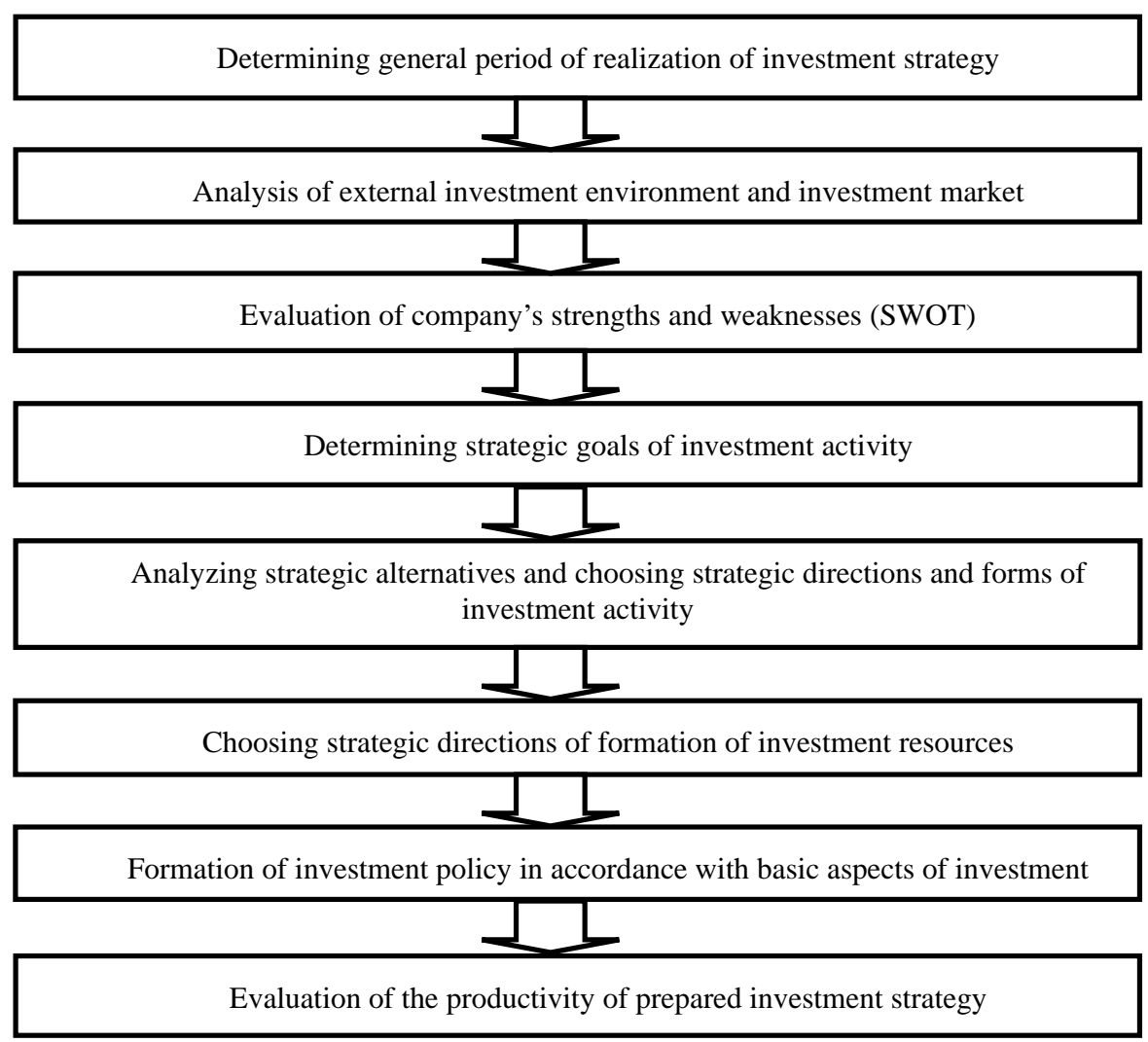

Figure 2. Stages of formation of company’s investment strategy (Blank, 2001).

\section{General Analysis of Investment Strategies of Local Companies in Azerbaijan}

The private sector has just started to develop in Azerbaijan, where the economy has been shifted from the administrative planned economy to free market economy since the collapse of the Soviet Union. Despite the continuous development of the private sector, many private business companies in Azerbaijan still suffer from many problems. These problems derive from many reasons and the most important one of them is that competitive market has not yet properly been established in Azerbaijan. This in due course negatively affects companies' internal and external investment policies. According to the Law of the Republic of Azerbaijan "on 
Investment Activity”, investment consists of financial resources, as well as material and intellectual assets invested in business and other means of activities for the purpose of income (profit) or social efficiency. Such resources and means consist of the followings:

- Money, bank deposits on purpose, credits, shares, stocks, and other securities;

- Movable and immovable property (buildings, constructions, equipments, and other means of material wealth);

- Scientific-experimental and other intellectual wealth duly registered;

- Sum of technical, technological, business, and other knowledge ("know-how”).

Investments in establishment of main funds and their re-production, as well as other ways of development of material production are realized through capital investments. In market economy it is not possible for companies to regulate activities of producing new value, without the existence of investment strategy. In this research about Azerbaijan, we have conducted a general analysis of investment activities of local companies, rather than statistic figures. Unreliability of statistic figures and difficulties in getting information from companies made us conduct such a general analysis. So, SWOT (Strength, Weakness, Opportunity, Threat) analysis has been conducted referring to basic criteria of general situation of companies in the country that may have an influence on investment activities. SWOT analysis of companies has two advantages: Firstly, SWOT analysis clarifies the general state of companies in the country, and secondly, SWOT is an analysis of "future situation” and helps to clarify companies' investment strategies. Table 1 reflects a general SWOT analysis of factors that have an influence on investment activities of local companies working in Azerbaijan.

Table 1

General SWOT Analysis of Factors That Have an Influence on Investment Activities of Local Companies Working in Azerbaijan

\begin{tabular}{|c|c|}
\hline Strength & Weakness \\
\hline $\begin{array}{l}\text { - } \quad \text { High market shares of big companies; } \\
\text { - } \quad \text { Companies' control over the market; } \\
\text { - } \quad \text { Efficient management; } \\
\text { - } \quad \text { Existence of motivation; } \\
\text { - } \quad \text { Financial status; } \\
\text { Width of demand in the country. }\end{array}$ & $\begin{array}{l}\text { - Use of technology in an old way. It decreases the } \\
\text { chances of effective use of resources and causes } \\
\text { more damage to environment; } \\
\text { - } \quad \text { Import of the part of equipments used in production; } \\
\text { - } \quad \text { Weaknese of good experience of companies; } \\
\text { - } \quad \text { Old technology; } \\
\text { - Weakness of strategic targets; } \\
\text { - Use of foreign investment funds. }\end{array}$ \\
\hline Opportunity & Threat \\
\hline $\begin{array}{l}\text { - Wide opportunities of increasing the volume of } \\
\text { production in the country; } \\
\text { - } \quad \text { Increasing demand in the market; } \\
\text { - } \quad \text { Incrication of new technologies; } \\
\text { - } \quad \text { Reduction of costs spent for raw materials; } \\
\text { - } \quad \text { Government propaganda (tax, customs, and other } \\
\text { - } \quad \text { Econcessions); } \\
\text { - } \quad \text { Opportunities of gaining new clients. }\end{array}$ & $\begin{array}{ll}\text { - } & \text { Emergence of new rivals; } \\
\text { - } & \text { Agreeing the prices with government authorities; } \\
\text { - } & \text { Deficiencies in management; } \\
\text { - } & \text { Inexperienced employees; } \\
\text { - } \quad \text { Weak scientific-technical progress (or weak } \\
\text { innovations); } \\
\text { - } \quad \text { High inflation in the country; } \\
\text { - } \quad \text { Change of wills and wishes of consumers; } \\
\text { High interest rates for credits at banks. }\end{array}$ \\
\hline
\end{tabular}

Paying attention to investment activities of companies we can conclude that their investment strategies consist of solely their investment projects on the directions of their activities. Moreover, these projects are not 
implemented at the same time, but consecutively. A Major portion of investments in the country is real investments. Such investments are now the only directions of the majority of the companies' investment activities and this significantly increases the importance of management of real investments in the system of investment activities of these companies. As obvious from the aforementioned analysis, despite the low level of investment activities of companies in Azerbaijan, there are huge opportunities for larger investment activities in the country. This is a chance for companies and the government shall take necessary measures to eradicate the factors preventing companies from taking advantage of this chance.

In recent years there have been significant quality changes toward this direction in the economy of the country. More attention is paid to the formation of main investment policy and significant quality changes have been made for the structural development of the economy with the help of investments. For this purpose, investment policy is being worked out, as investments play an important role in the development of economic mechanisms. Improvement and enlargement of investment activities of companies positively influence the development of macro-micro economy of the country. This development in due course ensures balanced economy, increase of its efficiency, and growth of national incomes.

\section{Conclusions}

In market economies, one of the specific features of investment policy is that investments increase the weight of expenses for equipments and machines and are directed to improve supply of companies with technologies and to restructure the companies. Increase of expenses on this direction causes the renewal of major means of production in the country. So, within this research on investment activities of companies, the following issues have been clarified, a number of conclusions have been made, and the companies working in Azerbaijan shall pay attention to the following points:

- The investment strategy of a company shall ensure its vision determined in advance and realization of its general activity strategy;

- The objective of an investment strategy is to make links among company's investment activities and choose and include the most effective of them to the portfolio;

- As a company's general strategy, investment strategy also starts with analysis of the external environment and evaluation of the internal state of the company;

- Creation of portfolio of various projects funded from various sources is only possible on the basis of common investment strategy;

- Basis of the investment strategy of a company consists of projects and effectiveness of the strategy depends on the effectiveness of these projects. However, initial strategy is formed and later projects emerge in order to realize the strategy;

- The investment strategy of a company determines field and regional directions of company's investment activities;

- Regardless of the form of investment, risks are inevitable in the realization of any investment project. What can companies do is only to identify, evaluate, and reduce the effect of such risks.

In order to improve investment strategies of companies in Azerbaijan, it is necessary to make investments not solely as reactions to the external environment through adaptive changes, but also through making own changes, to direct investments to increase the volume of production in order to maintain market share considering future forecasts of rival companies, and to establish strategic economic zones in order to manage 
common investment projects. Moreover, considering the government's role in regulating prices, companies shall control the costs of products so that they do not exceed the prices determined by the government.

\section{References}

Ahmadov, F. (2010). Analysis of the influence of the foreign direct investment to Azerbaijan to the national competeivness of Azerbaijan. Proceedings from International Conference of the Social Sciences in Balkans. Prizren University, Kosova, Prizren.

Ahmadov, F. (2011a). Analysis of the application of social responsibility by domestic businesses in Azerbaijan and its influence on the competitiveness of the country. Proceedings from International Conference on Corporate Social Responsibility. Loyola University, New Orleans, USA.

Ahmadov, F. (2011b). Competiveness power analysis of import and new directions in the foreign trade performance of Azerbaijan. Proceedings from the Social Sciences' Conference in Balkans. Tuzla University, Bosnia and Herzegovina.

Coates, R. (2006). Investment strategy. New York: McGraw-Hill.

Gedik, T., Cemil, K., \& Akyüz, I. (2005). Preparation and evaluation of the investment projects: Analyzing the methods of internal return and net present value. Turkey, Trabzon: Journal of the Bartin Faculty of Forestry.

Gordon, M., \& Daniel, G. (2011). The investment answer: Learn to manage your money \& protect your financial future. USA: Penguin Group.

Kaptan, S. S. (2002). Investment management. New Delhi: Sarup and Sons.

Kleyner, T. V. (1998). The business strategy: Analytical reference (Стратегии бизнеса: Аналитический справочник). Moscow.

Laxmetkina, N. N. (2002). Strategy of investment company (Инвестиционная стратегия предприятия). Moscow.

Ostrowska, E. (2002). Managing risk in investment (Ryzyko projektów inwestycyjnych). Warszawa: PWE.

Robert, L. H. (2004). Investment management_-Portfolio diversification, risk, and timing fact and fiction. Hoboken, New Jersey, Canada: John Willey \& Sons.

Stanyer, P., \& Dimson, E. (2006). Guide to investment strategy: How to understand markets, risk, rewards and behavior. London: Bloomberg. 